GEOGRAFICKÝ ČASOPIS / GEOGRAPHICAL JOURNAL 73 (2021) 3, 265-282

DOl: https://doi.org/10.31577/geogrcas.2021.73.3.14

\title{
WATERFALLS OF THE EASTERN CARPATHIANS (UKRAINE) AS OBJECTS OF GEOHERITAGE AND GEOTOURISM
}

\author{
Mykhailo Rutynskyi*, Halyna Kushniruk* \\ * Ivan Franko National University of Lviv, Faculty of Geography, Doroshenka 41, 79000 Lviv, Ukraine \\ mykhailo.rutynskyi@lnu.edu.ua, halyna.kushniruk@lnu.edu.ua
}

\begin{abstract}
Waterfalls of the Eastern Carpathians (Ukraine) as objects of geoheritage and geotourism

The aim of the paper is to cover the results of the study of mountain waterfalls in Ukraine in the context of assessment of the state and problems of geoheritage preservation and geotourism development in the Eastern Carpathians. The state of tourist infrastructure near waterfalls was analyzed in the study. For the first time the tendency and share of attraction of waterfalls by tour operators in programs of thematic geotours and mass excursion tours in the Carpathians were analyzed. A number of expert recommendations have been developed for regional authorities on the protection of waterfalls through the further development of the geoheritage network (opening small geoparks and local geodestinations with the status of "protected tracts"), the inclusion of attractive waterfalls in the branding and PR-promotion of values, routes and trails of sustainable geotourism in the Eastern Carpathians.
\end{abstract}

Key words: geotourism, geoheritage, geoparks, waterfalls, Eastern Carpathians

\section{INTRODUCTION}

Waterfalls are unique objects of geoheritage and tourism. They are a source of visual information on the geological structure of rocks, tectonic movements of the earth's crust and the activity of water-erosion processes in the past and present. On the other hand, no less important is the aesthetic value of waterfalls. The highest concentrations of excursion flows in mountainous areas are usually located near waterfalls (Hudson 2013a). With the development of mass tourism, waterfalls are increasingly beginning to serve as geotourism business cards that represent landscape expressiveness and emphasize the aesthetic appeal of a particular locality. However, the functions of waterfalls should be more clearly demarcated, on the one hand, as objects of mass nature-cognitive tourism (often - overtourism), on the other hand, as objects of sustainable thematic geotourism and representatives of the geoheritage and geodiversity of mountain ranges.

Nowadays, mass organized and amateur tourism is increasingly disturbing the "natural tranquility" of waterfalls, even in hard-to-reach areas. The local business is interested in the recreational infrastructure of the surrounding areas and the opening of tourist service facilities as close as possible to the new waterfalls advertised by tourists through blogs and social networks. Sustainable geotourism is the only compromise tool for reconciling multi-vector goals: nature conservation and tourist activity. The international community is working on the legal, institutional and promotional levers to reach a compromise on the conservation of the region's geoheritage in the conditions of rapidly increasing mass tourism. The experience of the countries of the Alpine zone of Europe is a benchmark (Frey et al. 2006, Wimbledon and Smith-Meyer 2012, Hose, ed., 2016 and Singh et al., eds. 2021). Ukraine should implement this experience. It is necessary to take more active steps in the 
cadastre of geoheritage of the Eastern Carpathians, the formation of a network of small geoparks and geodestinations, social promotion of the values of geotourism. In such realities, the practical value of expert studies of the Eastern Carpathian waterfalls as objects of geoheritage and geotourism is increasing.

\section{LITERATURE REVIEW}

The literature on geology, erosion geomorphology and hydrography of waterfalls includes hundreds of works written at different times and in different languages on both general and narrow subjects (Hudson 2013b and Grotzinger et al. 2019). However, the realities of an increasing anthropogenic load on hydraulic systems, declining areas of natural landscapes-catchments, the growth of mass tourist flows to recently pristine corners of nature pose new challenges for scholars in interdisciplinary research aimed at solving specific problems of the interaction of the system of "humanity - waterfalls" (Hudson 2013a).

Hudson (1998) was one of the first to outline the range of contemporary problems of the coexistence of waterfalls and the tourism business: "as resources for tourism, waterfalls play important roles in many countries, in both the 'developed' and 'developing' worlds. (...) With the expansion of naturebased or eco-tourism, we can expect many more pristine waterfalls to be 'brought into production' as scenic resources, and others, already developed for tourism, more intensively exploited. We must try to ensure that these natural resources, long admired for their beauty, will be managed in a way that makes the term 'sustainable' something more than a tourist industry catchword" (Hudson 1998, pp. $24-25$ ). Thus, a number of leading scientists in the last quarter of the twentieth century declared the necessity of introducing regulated soft geotourism that does not carry devastating threats to the objects of the geoheritage (Hudson 1998, Middleton and Hawkins 1998 and others). Ruban has reviewed the professional literature on geotourism in recent decades (Ruban 2015).

In the case of waterfalls, the policy of sustainable tourism implies the preservation of their nature conservation status or at least the rules of regulated access in order to counteract overtourism and the resulting geodigression (Hudson 2006, Weaver 2006 and Singh et al., eds. 2021). Today, the areas with the most attractive waterfalls are usually declared biosphere reserves, national parks, landscape parks and geoparks. These territories adhere to clear rules of tourism and conservation of geoheritage (Frey et al. 2006, Warszyńska-Jackowska, ed. 2007, Kurek 2008, Rutynskyi and Stetsyuk 2008, Zinko and Teres 2009, Bubniak et al. 2011, QuiriniPopławski 2011, Armaitiene et al. 2014 and Więckowski 2020). However, it does not always protect the most popular waterfalls from peaks of overtouristic loads.

On the other hand, thousands of waterfalls are still outside the conservation network in very vulnerable conditions of population growth, settlement network, forest, agrarian and tourist activity. In such realities, the efforts of scientists and the public on the preservation of geodiversity (Wimbledon and Smith-Meyer 2012 and Gray 2013), development of the network of geoparks (Frey et al. 2006, Brilha 2018 and Więckowski and Saarinen 2019), promotion of geo-education and values of the geoheritage (Crofts 2014 and Reynard and Giusti 2018), socially oriented marketing of geotourism (Chhabra, ed. 2010), promotion in the society of a new naturecognitive aesthetically-emotional approach to trips to waterfalls from the position of a geotourist (Dowling and Newsome, eds. 2006, 2010 and 2018, Haghe 2011, 
Quirini-Popławski 2011, Oviedo-García et al. 2019 and Ortega-Becerril et al. 2019) are becoming increasingly important.

In Ukraine, the problems of studying, preserving and tourist use of waterfalls are covered in a number of works, usually in Ukrainian (Gulych 2004, Zinko and Teres 2009, Bubniak et al. 2011 and 2013, Giletskyi 2013, Khilchevskyi et al. 2017, Kovalchuk and Kovalchuk 2018, etc.). Scientists of the Ivan Franko National University of Lviv in 2012 developed and published the concept of creating a network of geoparks in the western region of Ukraine (Bogucki et al. 2012). In particular, a general overview of the potential of ecotourism \& geotourism in Ukraine has been made (Kiptenko et al. 2017). Bayrak and Teodorovych (2020), with the example of the Beskid Mountains, demonstrated a modern approach to rating geological and geomorphological objects of the Ukrainian Carpathians for the further creation of geotourist routes.

At the initiative of Y. Zinko and O. Shevchuk, Ivan Franko National University of Lviv scientists have developed a project for the building of a cross-border (Ukrainian-Polish) geotourism path "Geo-Carpathians" (Zinko and Teres 2009 and Bubniak et al. 2013) and projects for the opening of the first geoparks "Rocky Beskids" and "Volcanic Carpathians" in the Eastern Carpathians (Malska et al. 2016).

\section{STUDY AREA}

The Eastern Carpathians extend in the western part of Ukraine near the borders of the EU countries - Poland, Slovakia, Hungary and Romania. Mountains with foothills are localized within four administrative regions - Lviv, Ivano-Frankivsk, Chernivtsi and Transcarpathia. They are the landscape basis for integration of these areas into the Carpathian tourist region of Ukraine $\left(21,000 \mathrm{~km}^{2}\right)$. At the same time, thanks to the implementation of the cross-border European integration initiative, since 1993 this region of Ukraine has been a part of the Carpathian Euroregion, which also covers the neighboring border mountain and foothill territories of Poland, Slovakia, Hungary and Romania. The Carpathian Euroregion is an effective form of cross-border cluster organization of economy, tourism, social initiatives, and nature protection. Today, the Euroregion is the institutional basis for the introduction of EU standards (Kozak et al. 2013, Quirini-Popławski 2016 and Nikolova and Sinnyovsky 2019) for geoconservation, geoheritage protection and normalized geotourism in the Eastern Carpathians in Ukraine.

\section{METHODS}

Methods of research of geotourism attraction of natural objects, which is based on an expert scoring of indicators, are described in detail in a number of textbooks and original methodological works of scientists. The authors' research is based on the methodological principles of assessing the basic and additional values of geoheritage. As well as this, much attention is paid to the use of a quantitative approach (point), which is described in detail in the works of Feig and Stokes (2011), Torabi Farsani et al., eds. (2011), Kubalíková (2013), Chen et al., eds. (2015), Dowling and Newsome, eds. (2018) and Kuleta (2018).

The cartographic basis of the study is the expert synthesis of large-scale maps of the region - geological, geomorphological and hydrological, the maps of the net- 
work of nature conservation areas, as well as the maps of the network of tourist mountain hiking routes and trails. It allowed us to group the waterfalls of the region by the uniqueness of geological and hydrological parameters, georepresentativeness in the system of orographic units of the Eastern Carpathians, the presence of nature conservation status and the degree of involvement in the network of tourism routes.

In 2019, field studies of waterfalls of the Eastern Carpathians were conducted by an initiative group of teachers and students of the Lviv Institute of Economics and Tourism under the coordination of the authors of the article. In particular, the following methods were used on the terrain: specialized methods of field geomorphological and landscape surveying of terrain, determination of geodiversity index (Ruban 2010), landscape aesthetic index, methods of statistical accounting of peak (at weekends) recreational loads near waterfalls and documentation of manifestations of recreational landscape digression. The study also used qualitativequantitative methods for assessing geodiversity (Kubalíková 2013, Zwoliński et al. 2018 and Kuleta 2018).

The information collected during the field surveys was systematized and ranked. Valuable ratings of waterfalls in the region as objects of geoheritage and objects of geotourism have been compiled. The severity of the problem of overtourism in the peak recreational load in the group of the most famous waterfalls in the Eastern Carpathians has been identified. A questionnaire survey of amateur visitors and representatives of organized excursion groups was conducted. Information on the vision of tourism business about the value of waterfalls in strategies for the development of mass excursion and thematic ecotourism \& geotourism in Ukraine was collected and systematized by the method of questioning the employees of the tourist companies of the region, who direct tourists from cities and resorts for excursions to the waterfalls.

The collected data was processed in the statistical program Statgraphics Plus V5.1 International Professional. Using a procedure with successive reduction of a group of variables to construct a regression model of the dependence of the geotourist attraction of waterfalls on various indicators, statistically qualitative models were obtained from the indicators that are significant. It was found that all the collected indicators are statistically significant, but have different effects on the geotourism attraction of waterfalls. A cluster analysis of the data array was performed using the Ward's Method (Hennig et al., eds. 2015).

\section{PRESENTATION OF THE MAIN RESEARCH MATERIAL}

The Carpathian region is of particular importance for Ukraine. After the illegal annexation of Crimea, it is the only mountainous region of Ukraine. The region has the highest rates of mountain and foothill geodiversity; the largest percentage of the nature reserve fund; the most developed infrastructure of mountain resorts, Spa \& wellness and sports tourism; the highest rates of tourist arrivals in any season (Rutynskyi and Stetsyuk 2008).

The mountainous relief, little changed landscapes and elements of hydrography of the Eastern Carpathians form the basis of the region's natural tourist resources. Waterfalls are the geotourism business cards of the Carpathian Mountains. There are 84 waterfalls on the mountain rivers with a height difference of more than $3 \mathrm{~m}$ (in addition, there are hundreds of unaccounted low-water and seasonal mini- 
waterfalls on mountain streams). Of these 84 waterfalls, $46(54,8 \%)$ are protected by the state as part of the nature reserve fund. Forty nine waterfalls $(58,3 \%)$ are included in mass tourism routes, and every year they experience an increasing overtourism load (Fig. 1). The development of the forestry business, on the one hand, social networks and fashion for amateur mountain trips, on the other hand, have increased the anthropogenic pressure on a group of environmentally vulnerable small waterfalls in the inaccessible tracts of the Eastern Carpathians.

In 2019, field studies of the waterfalls of the Eastern Carpathians were conducted by an initiative group of teachers and students of the Lviv Institute of Economy and Tourism under the coordination of the authors of the article. In the course of these studies, researchers met with tourists and guides near a number of waterfalls, who came by bus from different cities and resorts on excursions to these natural attractions.

Thus, a professional exchange of views with the practicing organizers of tours to the waterfalls took place. Practitioners have confirmed that in recent years, geotours and ecotours have been increasingly organized for groups of scientists, students, and environmental activists. However, they focused on the problem of a small number of requests for commercial tours of classical geotourism with appropriate scientific geological and geomorphological support. They stated that the offers of travel agencies are currently dominated by typical complex nature tours with visiting attractive waterfalls and other natural sites.

- For scoring the index of landscape aesthetics (emotional assessment (on a scale from 0 to 6) of the beauty of the waterfall), a sample of 370 visitors of all ages was interviewed using the open questionnaire method;

- For scoring the Geotourism attraction index $\left(\mathrm{I}_{\mathrm{ga}}\right)$ of the waterfall from the point of view of the expert environment, a sample of 24 guides (practitionersorganizers of geotourism) were interviewed using the open questionnaire method.

At the same time, 24 guides (most of them with the professional higher natural science education) agreed to take the survey. One of the main questions of the questionnaire was: "Give your own expert assessment on a scale from 0 to 6 to each of the 84 waterfalls of the Eastern Carpathians listed in the table, regarding their potential attractiveness for the further creation of geotourist routes". The results of this assessment were statistically processed in Excel. For each waterfall a statistical indicator $\mathrm{I}_{\mathrm{ga}}$ was calculated as the ratio of the sum of points assigned to this waterfall by respondents to the number of waterfalls.

The maximum value of the index is equal to $1.71(24 \times 6 / 84=1.71)-$ the highest score (the situation when all 24 respondents assigned the waterfall the highest point of attraction). Thus, the geotourism attraction index $\left(\mathrm{I}_{\mathrm{ga}}\right)$ of each waterfall was obtained. This is an approximate indicator that illustrates the practical visions of the tourism industry on the value of waterfalls in strategies for the development of thematic geotourism in the Eastern Carpathians.

The most protected (Law of Ukraine "On The Nature Reserve Fund of Ukraine") is a group of 46 waterfalls within Biosphere Reserves, Nature Reserves and National Parks (Tab. 1). 


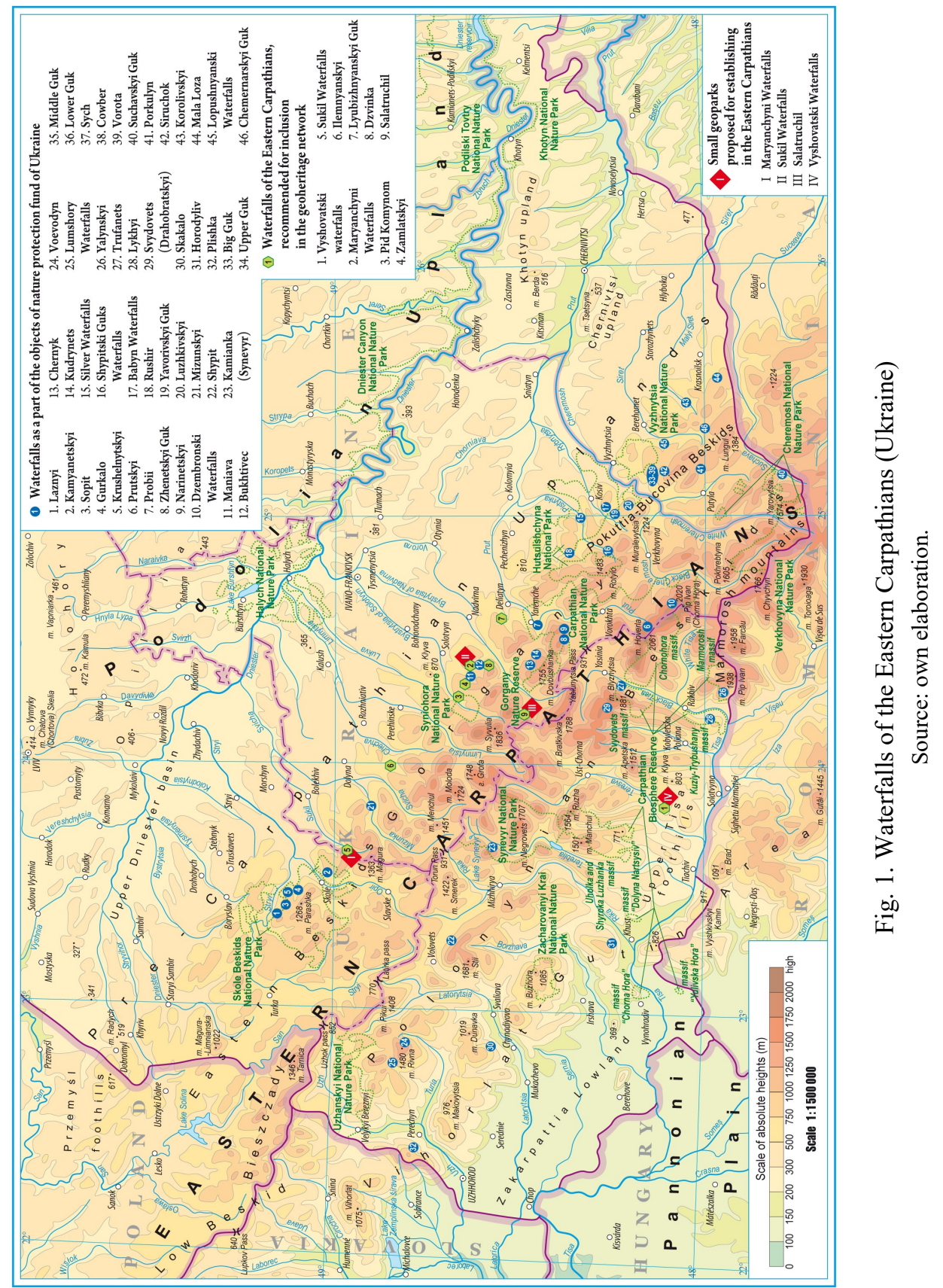


GEOGRAFICKÝ ČASOPIS / GEOGRAPHICAL JOURNAL 73 (2021) 3, 265-282

Tab. 1. Waterfalls as a part of the objects of nature protection fund of Ukraine

\begin{tabular}{|c|c|c|c|c|}
\hline $\mathrm{No}^{\circ}$ & $\begin{array}{l}\text { Name of the waterfall, } \\
\text { height }(\mathrm{m})\end{array}$ & $\begin{array}{c}\text { Location, } \\
\text { administrative } \\
\text { district }\end{array}$ & Nature conservation status & $* \mathrm{I}_{\mathrm{ga}}$ \\
\hline \multicolumn{5}{|c|}{ Lviv region } \\
\hline 1 & Laznyi, 10.5 & Drohobych district & $\begin{array}{l}\text { Hydrological Nature Monument in the } \\
\text { Skolivski Beskydy National Nature Park }\end{array}$ & 1.66 \\
\hline 2 & Kamyanetskyi, 6 & Skole district & $\begin{array}{l}\text { Hydrological Nature Monument in the } \\
\text { Skolivski Beskydy National Nature Park }\end{array}$ & 1.43 \\
\hline 3 & Sopit, 8 & Skole district & $\begin{array}{l}\text { Hydrological Nature Monument in the } \\
\text { Skolivski Beskydy National Nature Park }\end{array}$ & 1.32 \\
\hline 4 & Gurkalo, 5 & Skole district & $\begin{array}{l}\text { Hydrological Nature Monument in the } \\
\text { Skolivski Beskydy National Nature Park }\end{array}$ & 1.21 \\
\hline 5 & Krushelnytskyi, 3 & Skole district & Skolivski Beskydy National Nature Park & 0.34 \\
\hline \multicolumn{5}{|c|}{ Ivano-Frankivsk region } \\
\hline 6 & $\begin{array}{l}\text { Prutskyi, }(\max 12, \\
6 \text { cascades) }\end{array}$ & Nadvirna district & $\begin{array}{l}\text { Carpathian National Nature Park. The } \\
\text { waterfall flows between the foothills } \\
\text { of the Hoverla and Breskul mountains, } \\
\text { at the edge of the glacial crust, where } \\
\text { the Prut River originates. }\end{array}$ & 1.71 \\
\hline 7 & Probii, 8 & Yaremche & Carpathian National Nature Park & 1.71 \\
\hline 8 & Zhenetskyi Guk, 15 & Yaremche & Carpathian National Nature Park & 1.70 \\
\hline 9 & Narinetskyi, 10 & Yaremche & Carpathian National Nature Park & 0.68 \\
\hline 10 & $\begin{array}{l}\text { Dzembronski Waterfalls } \\
\text { (max 10, cascades) }\end{array}$ & $\begin{array}{l}\text { Verkhovyna } \\
\text { district }\end{array}$ & Carpathian National Nature Park & 0.82 \\
\hline 11 & Maniava, 17.5 & $\begin{array}{l}\text { Bohorodchany } \\
\text { district }\end{array}$ & Hydrological Nature Monument & 1.71 \\
\hline 12 & Bukhtivec, 8 & Nadvirna district & $\begin{array}{l}\text { Hydrological Nature Monument } \\
\text { in the reserve "Falcon Rocks" }\end{array}$ & 1.04 \\
\hline 13 & Chernyk, 7 & Nadvirna district & Hydrological Nature Monument & 0.64 \\
\hline 14 & Kudrynets, 6,5 & Nadvirna district & Hydrological Nature Monument & 0.72 \\
\hline 15 & $\begin{array}{l}\text { Silver Waterfalls, } 4,5 \\
(3 \text { cascades })\end{array}$ & Kosiv district & $\begin{array}{l}\text { Hydrological Nature Monument } \\
\text { in the NNP "Hutsulshchyna" }\end{array}$ & 1.57 \\
\hline 16 & $\begin{array}{l}\text { Shypitski Guks Waterfalls, } \\
\text { (max } 8,4 \text { cascades) }\end{array}$ & Kosiv district & NNP "Hutsulshchyna" & 1.14 \\
\hline 17 & $\begin{array}{l}\text { Babyn Waterfalls, ( } \text { max. } \\
2.5 ; 3 \text { cascades) }\end{array}$ & Kosiv district & NNP "Hutsulshchyna" & 0.20 \\
\hline 18 & Rushir, 4 & Kosiv district & $\begin{array}{l}\text { Hydrological Nature Monument } \\
\text { in the NNP "Hutsulshchyna" }\end{array}$ & 0.52 \\
\hline 19 & Yavorivskyi Guk, 7 & Kosiv district & $\begin{array}{l}\text { Geological Nature Monument in the NNP } \\
\text { "Hutsulshchyna" }\end{array}$ & 0.54 \\
\hline 20 & Luzhkivskyi, 14 & Kosiv district & NNP "Hutsulshchyna" & 0.83 \\
\hline 21 & Mizunskyi, 3 & Dolyna district & Hydrological Nature Monument & 0.34 \\
\hline \multicolumn{5}{|c|}{ Transcarpathian region } \\
\hline 22 & Shypit, 14 (5 cascades) & Mizhhirya district & Hydrological Nature Monument & 1.71 \\
\hline 23 & Kamianka (Synevyr), 6 & Mizhhirya district & NNP "Synevyr" & 1.40 \\
\hline
\end{tabular}


GEOGRAFICKÝ ČASOPIS / GEOGRAPHICAL JOURNAL 73 (2021) 3, 265-282

Continuation of the Tab. 1.

\begin{tabular}{|c|c|c|c|c|}
\hline 24 & Voyevodyn, 9 & Perechyn district & $\begin{array}{l}\text { State ornithological reserve "Falcons } \\
\text { Rocks" }\end{array}$ & 1.14 \\
\hline 25 & $\begin{array}{l}\text { Lumshory Waterfalls, } \\
\text { (max } 4,5 \text { cascades) }\end{array}$ & Perechyn district & Hydrological Nature Monument & 1.55 \\
\hline 26 & $\begin{array}{l}\text { Yalynskyi, } 26 \\
\text { (1-cascade) }\end{array}$ & Rakhiv district & $\begin{array}{l}\text { The highest single-stage waterfall } \\
\text { in the Eastern Carpathians. Hydrological } \\
\text { Nature Monument in the Carpathian } \\
\text { Biosphere Reserve. }\end{array}$ & 1.12 \\
\hline 27 & $\begin{array}{l}\text { Trufanets, } 36 \\
\text { ( } 5 \text { cascades })\end{array}$ & Rakhiv district & $\begin{array}{l}\text { Hydrological Nature Monument in the } \\
\text { Carpathian Biosphere Reserve }\end{array}$ & 1.67 \\
\hline 28 & $\begin{array}{l}\text { Lykhyi, } 20 \\
\text { (1-cascade) }\end{array}$ & Rakhiv district & $\begin{array}{l}\text { Kuziysky Reserve Massif of the Carpathian } \\
\text { Biosphere Reserve }\end{array}$ & 0.85 \\
\hline 29 & Svydovets, 7 & Rakhiv district & $\begin{array}{l}\text { Hydrological Nature Monument } \\
\text { in the Carpathian Biosphere Reserve }\end{array}$ & 0.74 \\
\hline 30 & Skakalo (I), 4 & $\begin{array}{l}\text { Mukachevo } \\
\text { district }\end{array}$ & Hydrological Nature Monument & 0.97 \\
\hline 31 & Horodyliv, 5 & Khust district & Hydrological Nature Monument & 0.14 \\
\hline 32 & Plishka, 1 & Perechyn district & Hydrological Nature Monument & 0.16 \\
\hline \multicolumn{5}{|c|}{ Chernivtsi region } \\
\hline 33 & Big Guk, 19 & \multirow{7}{*}{ Putil district } & \multirow{7}{*}{$\begin{array}{l}\text { Bukovynian Waterfalls Landscape Reserve } \\
\text { (In the area of } 2 \mathrm{~km} \text { of the Smuhariv } \\
\text { riverbed, seven waterfalls from } 3 \text { to } 19 \mathrm{~m} \\
\text { beat through dense rocks of shale and } \\
\text { sandstone, which is a unique phenomenon } \\
\text { for the Eastern Carpathians.) }\end{array}$} & 0.72 \\
\hline 34 & Upper Guk, 7 & & & 0.21 \\
\hline 35 & $\begin{array}{l}\text { Middle Guk, } 11 \\
\text { (3 cascades) }\end{array}$ & & & 0.52 \\
\hline 36 & Lower Guk, 7 & & & 0.24 \\
\hline 37 & Sych, 10,8 & & & 1.32 \\
\hline 38 & Cowber, 3,5 & & & 0.47 \\
\hline 39 & Vorota, 3 & & & 0.10 \\
\hline 40 & Suchavskyi Guk, 6 & Putil district & Geological Reserve & 0.78 \\
\hline 41 & Porkulyn, 6 & Putil district & $\begin{array}{l}\text { Hydrological Nature Monument (since } \\
\text { 1993) }\end{array}$ & 0.64 \\
\hline 42 & Siruchok, 3 & Putil district & Geological Nature Monument & 0.24 \\
\hline 43 & Korolivskyi, 5 & \multirow{2}{*}{$\begin{array}{l}\text { Storozhynets } \\
\text { district } \\
\text { Storozhynets } \\
\text { district }\end{array}$} & $\begin{array}{l}\text { Hydrological Nature Monument (since } \\
\text { 1991) }\end{array}$ & 0.24 \\
\hline 44 & Mala Loza, 8 & & Geological Nature Monument (since 2008) & 0.14 \\
\hline 45 & $\begin{array}{l}\text { Lopushnyanski Waterfalls } \\
\text { (max 3.5, } 5 \text { cascades) }\end{array}$ & $\begin{array}{l}\text { Vyzhnytsya } \\
\text { district }\end{array}$ & $\begin{array}{l}\text { Geological Nature Monument (since 2005) } \\
\text { The waterfalls are devastated. }\end{array}$ & 0.06 \\
\hline 46 & Chemernarskyi Guk, 4 & $\begin{array}{l}\text { Vyzhnytsya } \\
\text { district }\end{array}$ & Geological Nature Monument (since 2005) & 0.18 \\
\hline
\end{tabular}

* Geotourism attraction index $\left(\mathrm{I}_{\mathrm{ga}}\right)$ is calculated based on the results of a survey of 24 guides of groups of tourists (employees of regional travel agencies). Each respondent gave their own expert assessment of the geotourism attraction of each of the 84 waterfalls of the Eastern Carpathians on a scale from 0 to 6 . The obtained index $(\max =1.71)$ is an average qualitative assessment of the geotourism attraction of the waterfall from the point of view of the expert environment of practitioners-organizers of geotourism in the Eastern Carpathians.

Source: own elaboration 
Waterfalls: Prutskyi, Probii, Zhenetskyi Guk, Manyavskyi, Laznyi, Shypit and Trufanets received the highest geotourism attraction index $\left(I_{\mathrm{ga}}=1.66-1.71\right)$ in the group of waterfalls that are part of the objects of the nature protection fund of Ukraine, from the point of view of the expert environment of practitionersorganizers of geotourism in the Eastern Carpathians.

Prutskyi (Hoverlyanskyi) Waterfall is a top destination and tourist business card of the Eastern Carpathians, Carpathian National Nature Park and the highest mountain of Ukraine Hoverla. It runs next to the marked climbing eco-route of Hoverla. Due to the popularity of the route and the low environmental awareness of some visitors, since 2000 it has been experiencing increasing overtourism loads. It needs stricter protection as a representative object of the Carpathian geoheritage.

Waterfall Probii is a top destination and tourist business card of the Eastern Carpathians, Carpathian National Nature Park and the oldest mountain resort Yaremche. It is one of the most powerful and deepest waterfalls in the Eastern Carpathians on the Prut River. The height of the water drop is $8 \mathrm{~m}$; the angle of inclination is almost $45^{\circ}$. An arch bridge was built over the waterfall for the convenience of tourists, and a rope bridge was built for extremes. There are gastronomic establishments and the largest in the Eastern Carpathians Yaremche souvenir market nearby.

Zhenetskyi Guk Waterfall in the Gorgany mountain massif was formed in the 1950s as a result of an abnormal flood on the Prut River. It consists of one cascade 15 meters high. There is a convenient entrance for transport. The waterfall is a top destination for mass tourism guests of the Yaremche resort and the Carpathian National Nature Park. Nearby there are gastronomic establishments, a souvenir market, a parking lot, from which an eco-trail is laid. The observation deck is located at the foot of the waterfall.

Waterfall Maniava is a top destination of eco \& geotourism. It is located in a picturesque 200 -meter canyon with walls up to $20 \mathrm{~m}$ high. The waterfall is included by tour operators in more than 20 combined bus tours in the Carpathians.

Laznyi Waterfall is the highest mountain waterfall in the Lviv region. It is a valuable object of the geoheritage of the Eastern Carpathians. The waterfall was formed in the place where the mountain stream Laznyi (a tributary of the river Stryi) crosses the rock massif of flysch rocks, from which the Carpathians are formed. It consists of three cascades. The difference in the height of the water drop is $10.5 \mathrm{~m}$. It is a hydrological and geotourism business card of the Skole Beskydy mountain massif. The waterfall undergoes significant anthropogenic loads due to its popularity among tourists in spring (after rains it reaches the peak of high water and picturesqueness), summer and winter (when the cascades freeze and form ice compositions).

Shypit Waterfall is a top destination for mass tourism in the Transcarpathian region. It is included in the tourist rating "7 natural wonders of Ukraine". It receives up to 1.4-2.0 million visitors annually. The waterfall is included by tour operators in more than 30 combined bus tours in the Carpathians. It is popular with both locals and many guests at a number of nearby thermal spa, wellness and ski resorts and green tourism centers.

Trufanets Waterfall - access of tourists is limited by the nature protection regime of the Carpathian Biosphere Reserve. 


\section{RESULTS}

Based on many years of field research and personal vision, the authors recommend including, in the network of geoheritage of Ukraine 9 waterfalls (with a high geotourism attraction index) of the Eastern Carpathians, 4 small geoparks and 5 local geodestinations with the status of "protected tracts" (Tab. 2). It should be noted that some waterfalls have already received the conservation status of "Hydrological Nature Monument", in particular Shypit waterfall. And the waterfalls, which have received the highest geotourism attraction index, but do not have nature conservation status, the authors recommend including in the list of objects of the nature protection fund of Ukraine, the status of small geoparks or "protected tracts".

Tab. 2. Waterfalls of the Eastern Carpathians with a high geotourism attraction index (recommended for inclusion in the geoheritage network by opening small geoparks and local geodestinations with the status of "protected tracts")

\begin{tabular}{|c|c|c|c|c|}
\hline $\mathrm{No}^{\circ}$ & $\begin{array}{l}\text { Name of the } \\
\text { waterfall, } \\
\text { height }(\mathrm{m})\end{array}$ & $\begin{array}{l}\text { Administrative } \\
\text { district }\end{array}$ & Location, description & $\mathrm{I}_{\mathrm{ga}}$ \\
\hline \multicolumn{5}{|c|}{ Transcarpathian region } \\
\hline 1 & $\begin{array}{l}\text { Vyshovatski } \\
\text { Waterfalls, } 14+ \\
10+2\end{array}$ & $\begin{array}{l}\text { Tyachiv } \\
\text { district }\end{array}$ & $\begin{array}{l}\text { On the Vashovaty stream (a tributary of the Teresva } \\
\text { river). Weather-seasonal action, available, little known. }\end{array}$ & 1.51 \\
\hline \multicolumn{5}{|c|}{ Ivano-Frankivsk region } \\
\hline 2 & $\begin{array}{l}\text { Maryanchyni } \\
\text { Waterfalls, } 16 \\
(3 \text { cascades })\end{array}$ & $\begin{array}{l}\text { Bohorodchany } \\
\text { district }\end{array}$ & $\begin{array}{l}\text { On the Kobyla stream (right tributary of the Manyavka } \\
\text { River). }\end{array}$ & 1.64 \\
\hline 3 & $\begin{array}{l}\text { Pid Komynom } \\
\text { verkhniy, } 12 \\
\text { ( } 3 \text { cascades) }\end{array}$ & $\begin{array}{l}\text { Bohorodchany } \\
\text { district }\end{array}$ & $\begin{array}{l}\text { On the nameless stream-tributary of the Bystrytsya } \\
\text { Solotvynska river. Hard to reach, little known. }\end{array}$ & 1.12 \\
\hline 4 & $\begin{array}{l}\text { Zamlatskyi, } 8 \\
\text { ( } 3 \text { cascades) }\end{array}$ & $\begin{array}{l}\text { Bohorodchany } \\
\text { district }\end{array}$ & $\begin{array}{l}\text { On the Zamlaky stream (a tributary of the Manyavka } \\
\text { River). Hard to reach, little known. }\end{array}$ & 1.14 \\
\hline 5 & $\begin{array}{l}\text { Sukil waterfalls, } \\
8\end{array}$ & $\begin{array}{l}\text { Bolekhiv } \\
\text { district }\end{array}$ & $\begin{array}{l}\text { On the streams, tributaries of the Sukil river. Easily } \\
\text { accessible, little known. }\end{array}$ & 1.43 \\
\hline 6 & Ilemnyanskyi, 8 & $\begin{array}{l}\text { Rozhnyativ } \\
\text { district }\end{array}$ & $\begin{array}{l}\text { On the nameless stream-tributary of the Ilemka river. } \\
\text { Easily accessible, little known. }\end{array}$ & 1.27 \\
\hline 7 & $\begin{array}{l}\text { Lyubizhnyansky } \\
\text { i Guk, } 5\end{array}$ & $\begin{array}{l}\text { Nadvirna } \\
\text { district }\end{array}$ & $\begin{array}{l}\text { On the Lyubizhnya River. Easily accessible, little } \\
\text { known. }\end{array}$ & 1.02 \\
\hline 8 & Dzvinka, 5.7 & $\begin{array}{l}\text { Nadvirna } \\
\text { district }\end{array}$ & $\begin{array}{l}\text { On the nameless stream-tributary of the Bukhtivets river. } \\
\text { Hard to reach, little known. }\end{array}$ & 1.08 \\
\hline 9 & $\begin{array}{l}\text { Salatruchil, } 6, \\
\text { ( } 2 \text { cascades })\end{array}$ & $\begin{array}{l}\text { Nadvirna } \\
\text { district }\end{array}$ & $\begin{array}{l}\text { On the Salatruchil stream. Easily accessible, little } \\
\text { known. }\end{array}$ & 1.24 \\
\hline
\end{tabular}

Source: own elaboration.

The proposed Geopark "Maryanchyni waterfalls" in the Gorgany mountain massif should extend the status of a geoheritage object to a group of small seasonally active waterfalls on the Kobyla stream (right tributary of the Manyavka River) in the area where the stream crosses a steep slope (the angle of the cascades $74-90^{\circ}$ ) with exits to the surface of flysch rocks. The total height of the water difference is $16 \mathrm{~m}$. The height of the highest waterfall is $12.5 \mathrm{~m}$, the average $4 \mathrm{~m}$, the lowest $1.5 \mathrm{~m}$. 
The proposed Geopark "Sukil waterfalls" in the Skole Beskydy mountain massif should extend the status of a geoheritage object to a group of small seasonally active waterfalls ( $\max 8 \mathrm{~m}$ ) on the tributaries of the Sukil River. The object is easily accessible to tourists. There are conditions nearby for the opening of a campsite and a center of geoeducation \& geotourism.

The proposed Geopark "Salatruchil" in the Gorgany mountain massif should extend the status of a geoheritage object to a cascading seasonally active waterfall on the Salatruchil stream. The geological uniqueness and landscape aesthetics of the object is added to by the combination of the lower cascade of the waterfall into a small lake, carved into the rock base during periods of abnormally high drains.

The proposed Geopark "Vyshovatski Waterfalls" near the village of Vyshovatyi in the Transcarpathian region should extend the status of a geoheritage object to a group of small periodically active waterfalls $(\max 14 \mathrm{~m})$ in the lowlands of the Eastern Carpathians. Waterfalls dry up in dry periods, but after showers and spring floods have high hydrometric indicators.

In 2019, an initiative group of teachers and students of the Lviv Institute of Economics and Tourism, coordinated by the authors of the article, conducted a survey using the open questionnaire method. Student-interviewers asked tourists and guides near a number of waterfalls, who come by bus from different cities and resorts on excursions to these natural attractions. Then the interviewers asked these visitors to give short oral answers about themselves and their impressions of visiting the waterfalls. The sample included 24 guides and 370 organized and individual tourists from Ukraine of different age, gender and social status. The results of the survey were processed according to the method described in the works on quantitative methods in tourism (Baggio and Klobas 2011 and Altinay et al. 2015).

Survey on flows and structure of tourism to the waterfalls of the Eastern Carpathians gave the following results: $9 \%$ of Ukrainian tourists gave a positive answer to self-identification as a geotourist and $19 \%$ as an ecotourist. On the other hand, when asked whether you belong to the category of "nature tourism with a soft touch", $71 \%$ of respondents gave a positive answer, indicating an increase in the values of caring for natural heritage and nature-oriented travel.

Ninety three \% of surveyed visitors were guests from Ukraine, 3.6\% from Poland and $2.1 \%$ from Belarus. Among Ukrainian tourists $24 \%$ were residents of the capital of Kyiv, 20\% residents of large cities in the western region, $31 \%$ residents of large cities in the centre and east of the country and $25 \%$ residents of towns and villages.

A survey among visitors to waterfalls in the samples of young people, middleaged and older guests (a total sample of 370 respondents) showed similar results in terms of motivation to travel to the mountains. Sixty four \% of young people purposefully choose mountain waterfalls as a priority must-see destination, given the fashion trends of selfie tourism (the desire to share their impressions and photos through social networks), $21 \%$ of young people include visiting waterfalls as a mandatory additional motive for hiking or climbing the top. In the group of middle -aged guests, $37 \%$ (older age - 18\%) called a visit to the waterfall the main motive for a tourist (excursion) trip.

When choosing waterfalls as a motive for the trip, $84 \%$ of tourists used the recommendations of friends on social networks, the Trip Advisor service and previ- 
ously browsed the sites of travel bloggers. Ninty two \% of tourists used the Google Maps application to navigate in the mountains.

The results of the survey among 24 guides of excursion groups of tourists (employees of regional travel agencies) deserve special attention. All interviewed guides approve the involvement of waterfalls in geotourism promotion projects in the Eastern Carpathians. However, only $25 \%$ of respondents predicted commercial success for thematic geotours in the next 5 years. Another $75 \%$ of respondents prefered further promotion and development of traditional tours with combined visits to top cultural and natural heritage destinations (including popular waterfalls, which are easily accessible by bus). The cost of such one-day combined tours on the market today ranges from 12 to 25 EUR, two-three-day tours from 44 to 86 EUR. The first 14 advertised waterfalls of top ratings with convenient entrances, parking lots and related service infrastructure are included in the tours. Tour operators do not include waterfalls, which are little known in the tourist market.

To analyze the geotourism value and attractiveness of waterfalls, the clustering of waterfalls was carried out. Significant advances in cluster analysis have been made in recent decades, and modern versions of the analysis are credible for the objectivity of the classification. Ward's method is considered to be one of such reliable procedures (Hennig et al., eds. 2015).

The results of calculations of Ward's procedure in the statistical program Statgraphics Plus V5.1 International Professional in the form of a dendrogram are shown in Fig. 2. It demonstrates the clustering of geotourism value and attractiveness of waterfalls.

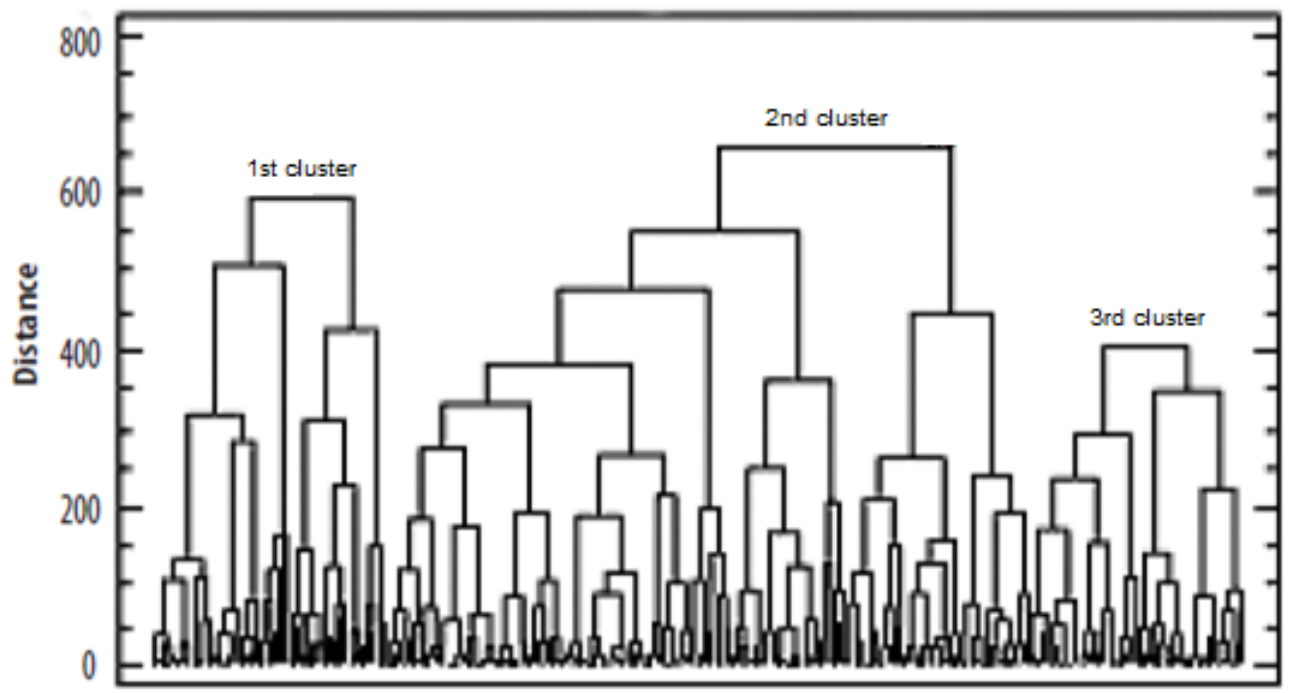

Fig. 2. The result of cluster analysis of geotourism value and attractiveness of the waterfalls of the Eastern Carpathians by Ward's method

Source: own elaboration.

For cluster analysis of geotourism value and attractiveness of waterfalls of the Eastern Carpathians by Ward's method, the authors used the indicators as follows: 
1. Height (specified by Plumb 1993). In terms of height, all waterfalls were divided into 5 groups with the assignment of the appropriate score.

2. Degree of georepresentativeness in the system of orographic units of the Eastern Carpathians. Based on the synthesis of thematic maps (from geological and hydrographic to landscape), the authors grouped the relevant geosystems into 5 groups with the assignment of the appropriate score.

3. Degree of involvement in the network of tourism routes. Based on the analysis of tourist maps, the authors grouped the waterfalls into 5 groups with the assignment of the appropriate score.

4. Peak values of the number of visits per day recorded during field research. Based on the obtained data, the authors grouped the waterfalls into 5 groups with the assignment of the appropriate score.

5. Index of landscape aesthetics (emotional assessment on a scale from 0 to 6 of the beauty of the waterfall by a sample of 370 interviewed visitors of all age groups).

6. Geotourism attraction index $\left(\mathrm{I}_{\mathrm{ga}}\right)$ of the waterfall from the point of view of the expert environment ( 24 interviewed guides - practitioners-organizers of geotourism in the Eastern Carpathians).

According to the above criteria, the calculated average values in each of the clusters show a clear cluster rating. The analysis of the results of clustering of waterfalls by the above criteria showed that three clusters on all dendrograms are clearly distinguished.

Clusters were ordered by increasing average values in them. The 1st cluster includes waterfalls that have low values according to these criteria, the 2 nd - waterfalls that have average values, the 3rd - waterfalls that have values above average for all criteria. The 1 st cluster included $33.33 \%$ of all waterfalls, the 2 nd $-28.66 \%$, and the $3 \mathrm{rd}-38.01 \%$.

Thus, $66.67 \%$ of waterfalls in the Eastern Carpathians have average and above average values by all evaluation criteria. This is the group of waterfalls where the experience of the European Union in geoconservation, geoheritage protection, geoeducation and geotourism should first of all be distributed.

\section{DISCUSSION AND CONCLUSIONS}

Researchers of the Carpathians in a number of original works of the last two decades, despite a wide discussion on the forms and methods of geoconservation, geoheritage protection, geoeducation and geotourism, demonstrate a unanimous opinion on the trend of anthropogenic (including tourist) load on mountain landscapes (Warszyńska-Jackowska ed. 2007, Kurek 2008, Rutynskyi and Stetsyuk 2008, Zinko and Teres 2009, Bubniak et al. 2011, Quirini-Popławski 2011, Bayrak and Teodorovych 2020, Więckowski 2020, etc.).

The current information society is increasing the amount of information about the natural attractions of the mountains, which significantly intensifies the attention of potential tourists to a number of geoheritage sites, which until recently were outside the traditional tourist routes (in the so-called "infor-mation shadow"). This trend, outlined by a number of researchers in the Pyrenees, the Alps and the Carpathians (Bubniak et al. 2013, Gray ed. 2013, Armaitiene et al. 2014, Quirini- 
Popławski 2016, Szpara 2016 and Oviedo-García et al. 2019), creates new challenges for the practices of nature conservation.

One of these challenges is to find a sustainable balance between the need to protect mountain waterfalls and the growing number of visits to these sites (Hudson 2013a, Giletskyi 2013 and Ortega-Becerril et al. 2019). The experience of EU member states demonstrates a consolidated approach to the rules for regulating excursion flows to environmentally vulnerable geoheritage sites and promoting sustainable geotourism practices (Wimbledon and Smith-Meyer, eds. 2012, Wiẹckowski 2013, Chen et al., eds. 2015, Hose, ed. 2016, Brilha 2018 and Nikolova and Sinnyovsky 2019).

The COVID-19 crisis for the period 2020 - 2021 an organized and amateur geotourism in the Eastern Carpathians has "frozen". However, it did not destroy the interest in waterfalls and the work of travel agencies in this direction.

As for the Eastern Carpathians, the authors state that the COVID-19 crisis in 2020 gave rise to the economic phenomenon of deferred demand. However, at the end of the spring of 2021, with the easing of quarantine restrictions and the revival of the trend of domestic nature tourism, this deferred demand, fueled by advertising and the work of popular travel bloggers, generated a consistently high demand for commercial tours to waterfalls and other geoheritage attractions (mostly tourists from Kyiv, Lviv, Ivano-Frankivsk, Truskavets, etc.).

At the beginning of summer 2021, the offer of a number of regional travel agencies already resumed the line of proposed nature tours to the Carpathians (subject to quarantine restrictions). The authors recently vacationed in the Carpathians and witnessed that the deferred demand for a year turned into an increase in demand from May 2021 for ecotours and geotours to the natural attractions of the Eastern Carpathians.

There is a direct correlation between mass tourist flows and the quality transport accessibility to the waterfalls of the Eastern Carpathians. The analysis indicates a lack of infrastructure near little-known waterfalls. There are no parking spaces near most of the waterfalls, which is a significant problem for amateur travelers. On the other hand, such realities of restraining tourism protect from excessive loads more than fifty waterfalls in anthropogenically vulnerable natural tracts of the Eastern Carpathians.

The priority tasks in the context of infrastructural support of geotourism in Ukraine are the creation of a system of geotourism information along mountain roads, marking of geotourism routes, arrangement of places for camping near waterfalls and other geoheritage sites. Many travelers, who plan their own trip, try to make it as autonomous and budget-friendly as possible and use their own means of transportation and accommodation, or travel on foot or hitchhiking. The network of campsites is focused on this category of tourists. Near most of the waterfalls of the Eastern Carpathians there are no places for camping, which causes discomfort to tourists traveling with a tent. According to our calculations, at least $120-150$ sites near top geotourism objects should be allocated, where travelers could pitch a tent and stay overnight. Investing in the development of a camping network in the Eastern Carpathians will promote the development of active types of "nature tourism with a soft touch" and increase the visiting of waterfalls.

According to the results of the study, nine waterfalls of the Eastern Carpathians are recommended for inclusion in the geoheritage network by opening 4 small ge- 
oparks and 5 local geodestinations with the status of "protected tracts". To promote them as objects of geotourism, it is necessary to develop Internet resources to promote geotourism in Ukraine; to build access roads from settlements; to pave marked trails to the waterfalls themselves; to install pointers with QR-codes of geotourism information near waterfalls and adjacent geological outcrops in a format that is easy to read on a smartphone; to promote geotourism guides free of charge via the Internet and TICs, which will help potential tourists to orientate themselves on the terrain and get to geotourism sites.

Ukraine should utilise the experience of the European Union (Nikolova and Sinnyovsky 2019 and Singh et al., eds. 2021) and more actively implement steps in the cadastre of geoheritage of the Eastern Carpathians, the formation of a network of small geoparks and geodestinations, social promotion of geotourism values. The tourist flow to these geoheritage sites should be limited and regulated. In such realities, the practical value of expert studies of the Eastern Carpathian waterfalls as objects of geoheritage and geotourism is increasing.

\section{REFERENCES}

ALTINAY, L., PARASKEVAS, A., JANG, S. (2015). Planning research in hospitality and tourism. London (Routledge). DOI: https://doi.org/10.4324/9781315723662.

ARMAITIENE, A., BERTUZYTE, R., VASKAITIS, E. (2014). Conceptual framework for rethinking of nature heritage management and health tourism in national parks. Procedia - Social and Behavioral Sciences, 148, 330-337. DOI: https://doi.org/10.1016/ j.sbspro.2014.07.050.

BAGGIO, R., KLOBAS, J. (2011). Quantitative methods in tourism. Bristol (Channel View). DOI: https://doi.org/10.21832/BAGGIO6195.

BAYRAK, G., TEODOROVYCH, L. (2020). Geological and geomorphological objects of the Ukrainian Carpathians' Beskid Mountains and their tourist attractiveness. Journal of Geology, Geography and Geoecology, 29, 16-29. DOI: https://doi.org/10.15421/ 112002.

BOGUCKI, A., BRUSAK, W., KRAWCZUK, J., MOSKALUK, K., SIRENKO, I., TOMENIUK, O., SZEWCZUK, O., ZINKO, J. (2012). Koncepcja i zasady tworzenia geoparkow na zachodzie Ukrainy. Annales UMCS. Sectio B. Geographia Geologia, Mineralogia et Petrographia, 68(2), 9-32. DOI: 10.2478/v10066-012-0017-4.

BRILHA, J. (2018). Geoheritage and geoparks. In Reynard E., Brilha J., eds. Geoheritage. assessment, protection, and management. Amsterdam (Elsevier), pp. 323-335. DOI: https://doi.org/10.1016/B978-0-12-809531-7.00018-6.

BUBNIAK I. M., SOLECKI A. T., ŚLIWINSSKI, W. R. (2011). Geoturistic attractions of Ukraine. In Słomka, T., ed. Geoturism. A variety of aspects. Kraków (AGH University of Sciences and Technology), pp. 113-127.

BUBNIAK, I., ZINKO, Y., MALSKA, M., SKAKUN, L., YATSOZYNSKYI, O., SALETSKIY, A. (2013). Geotourism attractions of the transboundary path "GeoCarpathians" (Ukrainian part). Visnyk of the Lviv University. Series Geography, 43, 309 -322. DOI: http://dx.doi.org/10.30970/vgg.2013.43.1732.

CROFTS, R. (2014). Promoting geodiversity: Learning lessons from biodiversity. Proceedings of the Geologists' Association, 125, 263-266. DOI: https://doi.org/10.1016/ j.pgeola.2014.03.002.

DOWLING, R., NEWSOME, D., eds. (2006). Geotourism. Oxford (Elsevier).

DOWLING, R., NEWSOME, D., eds. (2010). Global geotourism perspectives. Oxford (Goodfellow Publishers).

DOWLING, R., NEWSOME, D., eds. (2018). Handbook of geotourism. Cheltenham (Edward Elgar Publishing). 
FEIG, A. D., STOKES, A. (2011). Qualitative inquiry in geoscience education research. McLean (Geological Society of America). DOI: https://doi.org/10.1130/SPE474.

FREY, M.-L., SCHÄFER, K., BÜCHEL, G., PATZAK, M. (2006). Geoparks - a regional, European and global policy. In Dowling, R. K., Newsome, D., eds. Geotourism. Oxford (Butterworth-Heinemann), pp. 95-117. DOI: https://doi.org/10.1016/B978-0-7506-6215 $-4.50014-2$.

GILETSKYI, J. (2013). Waterfalls of the Ukrainian Carpathians as objects of cognitive tourism. Geography and Tourism, 26, 109-122.

GRAY, M., ed. (2013). Geodiversity: Valuing and conserving abiotic nature. Chichester (Wiley Blackwell). DOI: https://doi.org/10.1016/B978-0-12-809531-7.00001-0.

GROTZINGER, J., JORDAN, T. H., PRESS, F., SIEVER, R. (2019). Understanding Earth. New York (W. H. Freeman and Co.).

GULYCH, O. I. (2004). Recreational potential of the Ukrainian Carpathians and its current state development. Lviv (Institute of Regional Studies Publishing House).

HAGHE, J.-P. (2011). Do waterfalls have value in themselves? A metamorphosis in the values of the Gimel waterfall in France. Policy and Society, 30, 249-256. DOI: https:// doi.org/10.1016/j.polsoc.2011.10.008.

HENNIG, C., MEILA, M., MURTAGH, F., ROCCI, R., eds. (2015). Handbook of cluster analysis. New York (CRC Press). DOI: https://doi.org/10.1201/b19706.

HOSE, T., ed. (2016). Geoheritage and geotourism: A European perspective. Martlesham (Boydell \& Brewer).

HUDSON, B. J. (1998). Waterfalls resources for tourism. Annals of Tourism Research, 25, 958-973. DOI: https://doi.org/10.1016/S0160-7383(98)00043-7.

HUDSON, B. J. (2006). Waterfalls, tourism and landscape. Geography: An International Journal, 91, 3-12.

HUDSON, B. J. (2013a). Waterfall: Nature and culture. London (Reaktion Books).

HUDSON, B. J. (2013b). Waterfalls, science and aesthetics. Journal of Cultural Geography, 30, 356-379. DOI: https://doi.org/10.1080/08873631.2013.828482.

CHEN, A., Lu, Y., Ng, Y. C., eds. (2015). The principles of geotourism. Cham (Springer Nature)

CHHABRA, D., ed. (2010). Sustainable marketing of cultural and heritage tourism. London and New York (Routledge).

KHILCHEVSKYI, V. K., GOPCHENKO, E. D., LOBODA, N. S., OBODOVSKYI, O. G., GREBIN, V. V., SHAKIRZANOVA, ZH. R., YUSHCHENKO, Y. S, SHERSTYUK, N. P., OVCHARUK, V. A. (2017). Hydrological science in universities and perspectives of its further development in Ukraine. Ukrainian Hydrometeorological Journal, 6 (19), 90-105. DOI: https://doi.org/10.31481/uhmj.19.2017.11.

KIPTENKO, V., LYUBITSEWA, O., MALSKA, M., RUTYNSKYI, M., ZAN'KO, Y., ZINKO, Y. (2017). Geography of tourism of the Ukraine. In Widawski, K., Wyrzykowski, J., eds. Geography of tourism of Central and Eastern Europe countries. Basel (Springer International Publishing AG), pp. 509-551. DOI: https://doi.org/10.1007/9783-319-42205-3 13.

KOVALCHUK, A., KOVALCHUK, I. (2018). Atlas mapping of the river basin systems. Lviv (Prostir-M).

KOZAK, J., OSTAPOWICZ, K., BYTNEROWICZ, A., WYZGA, B. (2013). The Carpathians: Integrating nature and society towards sustainability. New York and London (Springer Science \& Business Media).

KUBALÍKOVÁ, L. (2013). Geomorphosite assessment for geotourism purposes. Czech Journal of Tourism, 2(2), 80-104. DOI: 10.2478/cjot-2013-0005.

KULETA, M. (2018). Geodiversity research methods in geotourism. Geosciences, 8, 197. DOI: https://doi.org/10.3390/geosciences8060197.

KUREK, W. (2008). Tourism in Polish Carpathians in the political transition time. In Wyrzykowski, J., ed. Conditions of the foreign tourist development in Central and Eastern Europe, tourism in geographical environment. Wrocław (Uniwersytet Wrocławski), pp. 295-302. 
MALSKA, M., ZINKO, Y., ANTONIUK, N. (2016). Ecotourism and geotourism in Ukraine. Journal of Geography, Politics and Society, 6(4), 27-33. DOI: https:// doi.org/10.4467/24512249JG.16.024.5811.

MIDDLETON, V., HAWKINS, R. (1998). Sustainable tourism: A marketing perspective. Oxford (Butterworth-Heinemann).

NIKOLOVA, V., SINNYOVSKY, D. (2019). Geoparks in the legal framework of the EU countries. Tourism Management Perspectives, 29, 141-147. DOI: https://doi.org/ 10.1016/j.tmp.2018.11.007.

ORTEGA-BECERRIL, J. A., POLO, I., BELMONTE, A. (2019). Waterfalls as geological value for Geotourism: the case of Ordesa and Monte Perdido National Park. Geoheritage, 11, 1199-1219. DOI: https://doi.org/10.1007/s12371-019-00366-1.

OVIEDO-GARCÍA, M. Á., VEGA-VÁZQUEZ, M., CASTELLANOS-VERDUGO, M., ORGAZ-AGÜERA, F. (2019). Tourism in protected areas and the impact of servicescape on tourist satisfaction, key in sustainability. Journal of Destination Marketing \& Management, 12, 74-83. DOI: https://doi.org/10.1016/j.jdmm.2019.02.005.

PLUMB, G. A. (1993). A scale for comparing the visual magnitude of waterfalls. EarthScience Reviews, 34, 261-270. DOI: https://doi.org/10.1016/0012-8252(93)90059-G.

QUIRINI-POPŁAWSKI, Ł. (2011). Walory przyrodnicze i kulturowe jako podstawa atrakcyjności turystycznej Beskidów Wschodnich na obszarze obwodów lwowskiego i iwanofrankowskiego (Ukraina). Prace Geograficzne, 125, 129-145.

QUIRINI-POPŁAWSKI, Ł. (2016). Zrównoważony rozwój turystyki na obszarach chronionych Karpat Ukraińskich. In Szpara, K., Wilkońska, A., Zawilińska, B., eds. Lokalny potencjat a zrównoważony rozwój turystyki w Karpatach. Kraków (UNEP), pp., 52-69.

REYNARD, E., GIUSTI, C. (2018). The landscape and the cultural value of geoheritage. In Reynard E., Brilha J., eds. Geoheritage. Assessment, Protection, and Management, Amsterdam (Elsevier), pp. 147-166. DOI: https://doi.org/10.1016/B978-0-12-8095317.00008-3.

RUBAN, D. A. (2010). Quantification of geodiversity and its loss. Proceedings of the Geologists' Association, 121, 326-333. DOI: https://doi.org/10.1016/j.pgeola.2010.07.002.

RUBAN, D. A. (2015). Geotourism - a geographical review of the literature. Tourism Management Perspectives, 15, 1-15. DOI: https://doi.org/10.1016/j.tmp.2015.03.005.

RUTYNSKYI, M. J., STETSYUK, O. V. (2008). Tourist complex of the Carpathian region of Ukraine. Chernivtsi (Books-XXI).

SZPARA, K. (2016). Rozwój ruchu turystycznego. In Wolski J., ed. Bojkowszczyzna Zachodnia-wczoraj dziś i jutro. Warsawa (IGiPZ PAN), pp. 445-472.

SINGH, R. B., WEI, D., ANAND, S., eds. (2021). Global geographical heritage, geoparks and geotourism: Geoconservation and development. Cham (Springer Nature).

TORABI FARSANI, N., COELHO, C., COSTA, C., eds. (2011). Geoparks and geotourism: New approaches to sustainability for the 21st century. Irvine (UniversalPublishers).

WARSZYNSSKA-JACKOWSKA, J., ed. (2007). Turystyka zrównoważona na obszarze Beskidów Zachodnich. Studium uwarunkowań $i$ barier rozwoju. Kraków (IGSMiE PAN).

WEAVER, D. (2006). Sustainable tourism: Theory and practice. Oxford (Elsevier Butterworth-Heinemann).

WIECKOWSKI, M. (2013). Eco-frontier in the mountainous borderlands of Central Europe. The case of Polish border parks. Journal of Alpine Research / Revue de géographie alpine, 101. DOI: https://doi.org/10.4000/rga.2107.

WIĘCKOWSKI, M. (2020). Natural heritage as a resource for tourism development in the Polish Carpathians. Geografický časopis, 72, 243-259. DOI: https://doi.org/10.31577/ geogrcas.2020.72.3.12.

WIECKOWSKI, M., SAARINEN, J. (2019). Tourism transitions, changes, and the creation of new spaces and places in Central-Eastern Europe. Geographia Polonica, 92, 369 377. DOI: https://doi.org/10.7163/GPol.0154. 
WIMBLEDON, W., SMITH-MEYER, S., eds. (2012). Geoheritage in Europe and its conservation. Oslo (ProGEO).

ZINKO, Y., TERES, V. (2009). Sustainable tourism in the Ukrainian Carpathians. In Castellani, V., Sala, V. S., eds. Sustainable tourism as a factor of local development. Trento (Tangram Edizioni Scientiche), pp. 70-81.

ZWOLINSKI, Z., NAJWER, A., GIARDINO, M. (2018). Methods for assessing geodiversity. In Reynard E., Brilha J., eds. Geoheritage. assessment, protection, and management, Amsterdam (Elsevier), pp. 27-52. DOI: https://doi.org/10.1016/B978-0-12809531-7.00002-2.

Mykhailo Rutynskyi, Halyna Kushniruk

\section{VODOPÁDY VÝCHODNÝCH KARPÁT (UKRAJINA) AKO OBJEKTY GEODEDIČSTVA A GEOTURIZMU}

Ciel’om práce bol výskum horských vodopádov na Ukrajine v kontexte hodnotenia ich stavu a problémov súvisiacich s ochranou geodedičstva (geologické a geomorfologické dedičstvo; angl. geoheritage) a rozvojom geoturizmu vo Východných Karpatoch.

V štúdii boli použité nasledujúce metódy: špecializované metódy terénneho geomorfologického a krajinného mapovania, estetický index krajiny, štatistické vyhodnotenie návštevnosti vodopádov počas turistickej špičky (víkendy), dokumentácia prejavov degradácie krajiny v dôsledku turizmu. Vykonaný bol taktiež sociologický prieskum medzi laickými návštevníkmi a reprezentantmi organizovaných turistických skupín. Pre potreby analýzy z hladiska ich geoturistickej hodnoty a atraktivity boli vodopády aplikovaním Wardovej metódy začlenené do troch klastrov.

Výsledkom práce je klasifikácia vodopádov daného regiónu vyplývajúca z ich hodnoty z hl'adiska geodedičstva a geoturizmu. Okrem toho bola zdokumentovaná závažnost' problému nadmernej návštevnosti najznámejších vodopádov Východných Karpát v čase turistickej špičky. Na základe výsledkov autori štúdie navrhujú devät' vodopádov Východných Karpát zaradit' do zoznamu objektov geodedičstva a ich ochranu zabezpečit otvorením štyroch malých geoparkov a vyhlásením piatich lokálnych osobitne „,chránených území" (angl. "protected tracts"). 